Article

\title{
Following, Challenging, or Shaping: Can Third Countries Influence EU Energy Policy?
}

\author{
Benjamin Hofmann ${ }^{1}$, Torbjørg Jevnaker ${ }^{2,3}$ and Philipp Thaler ${ }^{1, *}$ \\ ${ }^{1}$ Institute of Political Science, University of St. Gallen, 9000 St. Gallen, Switzerland; E-Mails: benjamin.hofmann@unisg.ch \\ (B.H.), philipp.thaler@unisg.ch (P.T.) \\ 2 Fridtjof Nansen Institute, 1326 Lysaker, Norway; E-Mail: tjevnaker@fni.no \\ ${ }^{3}$ Department of Political Science, University of Oslo, 0317 Oslo, Norway \\ * Corresponding author
}

Submitted: 30 November 2018 | Accepted: 17 January 2019 | Published: 28 March 2019

\begin{abstract}
Can non-EU member states influence the EU's energy policy? The Europeanization of energy policy in third countries is often described as a one-directional process in which these countries essentially adopt the EU energy acquis. Our article questions this dominant view by exploring whether and how third countries can influence the formulation and implementation of EU energy policy. We argue that relative differences in third country influence depend on their access to relevant venues and actors of EU policy-making as well as their structural power resources. We develop a typology linking these two factors to the outsider, follower, challenger, or shaper roles that third countries assume in EU energy governance. We empirically probe our argument in three case studies representing different models of EU-third country cooperation. Our cases include a group of nine Southeast and East European countries (Energy Community), Switzerland (bilateral arrangements), and Norway (European Economic Area). The analysis shows that it is access and structural power which together define the extent to which third countries are able to influence the formulation of EU energy policy and customize its implementation to their domestic needs. We find that while the Energy Community members are followers in EU energy governance, Switzerland and Norway are shapers. Strikingly, the influence of these two non-EU members may occasionally even surpass that of smaller EU member states. This highlights that third countries are not merely downloading EU energy regulation but sometimes also succeed in uploading their own preferences. Our contribution has implications for the post-Brexit EU-UK energy relations and qualifies claims about EU regulatory hegemony in the wider region.
\end{abstract}

\section{Keywords}

Brexit; Energy Community; energy policy; European Economic Area; European Union; Europeanization; influence; Norway; Switzerland; third country

\section{Issue}

This article is part of the issue “EU Energy Policy: Towards a Clean Energy Transition?”, edited by Kacper Szulecki and Dag Harald Claes (University of Oslo, Norway).

(C) 2019 by the authors; licensee Cogitatio (Lisbon, Portugal). This article is licensed under a Creative Commons Attribution 4.0 International License (CC BY).

\section{Introduction}

Can, and if so how, do non-members influence EU energy policy? Brexit has placed third country relations with the European Union (EU) in the spotlight. In the area of energy, different institutional arrangements for coordination between the EU and third countries exist, and these relationships are dynamic. For many years, Switzerland and the EU have been negotiating to extend their bilateral relations to an electricity agreement. Norway is a member of the European Economic Area (EEA) which involves dynamic cooperation in the sense that relevant EU energy laws are incorporated as they arise. Furthermore, the Energy Community (EnC), a multilateral frame- 
work between nine Southeast and East European countries and the EU to integrate their energy markets, is undergoing a reform process. Common to each of these relationships is the growing entanglement between EU and national policies, a process that EU scholarship refers to as 'Europeanization' (cf. Cowles, Caporaso, \& Risse, 2001). This entanglement can generally work in two directions; studies show how the EU influences member state policies and vice versa (cf. Featherstone \& Radaelli, 2003). Yet, Europeanization in energy relations with third countries is often described as a one-directional process where such countries adopt or "download" the EU energy acquis (i.e., the EU's accumulated legislation, legal acts, and court decisions relevant for the area of energy). The diffusion of EU regulation and norms beyond its external borders is held to exemplify the Union's regulatory and market power (Goldthau \& Sitter, 2015). This article seeks to advance the study of Europeanization of energy policy and third countries through a closer examination of the dynamics of third-country influence or "uploading" in EU energy governance.

We depart from the assumption that the relationship between the EU and third countries in the energy field is more nuanced than generally portrayed. Putting academic contributions with an EU-centric approach into perspective, we argue that third countries can indeed influence EU energy policy. However, third countries are not a homogeneous category but differ significantly in their ability to upload their preferences to the EU level. We explain relative differences in influence with reference to two variables: Third countries' access to venues and actors of EU policy-making (or lack thereof), and their structural power resources. Whereas access is a necessary precondition to creating channels of influence, structural power resources provide the political weight to utilize these channels. This differentiation accounts for variation in influence among countries that are subject to similar institutional relationships with the EU. Since we include structural power, we move beyond the purely institutionalist focus which characterizes this research field (cf. Godzimirski, 2019; Jegen 2009; Marcus et al., 2017). Our contribution is to explain the influence of third countries on EU energy policy as a function of two independent, yet intrinsically related variables.

The article proceeds in four steps. First, we review the literature on Europeanization in light of external and energy policy and develop a framework of third-country influence in EU energy governance. Second, we probe our arguments in three qualitative case studies, which include data from 15 interviews with experts from the EU and third countries. The cases represent different models of third-country institutional relations with the EU. They include a group of nine Southeast and East European countries (contracting parties of the EnC), Switzerland (bilateral arrangements with the EU), and Norway (member of the EEA). Third, we discuss the implications of our findings for differences in third country influence and for future research on Europeanization. Finally, we conclude by reviewing the implications of our main arguments for future EU-UK relations.

\section{A Framework of Third Country Roles in EU Energy Policy}

Since the late 1980s, European integration has made accelerated progress in the area of energy (Buchan, 2015; Thaler, 2016). As the Union's involvement grew internally, so did the influence on energy sectors beyond its territory. Arguably, the establishment of an internal energy market and national targets for renewable energy sources have had most impact on the energy policy of third countries. Physical interconnectedness of electricity grids and pipeline systems, participation in the internal energy market, and the definition of common goals for renewable energy sources required coordination and approximation of rules-not only within the EU but also between the EU and third countries (cf. Buschle, 2014). Developments such as these have caused an increasing entanglement between EU and national levels of policy-making.

Academic research has captured the gradual expansion of supranational consequences and the underlying reciprocal dynamics between the EU and member state policies under the concept of 'Europeanization' (Cowles et al., 2001; Goetz \& Hix, 2000). While scholars emphasize different mechanisms of how European and national levels influence one another, broad agreement exists around the bi-directional nature of Europeanization (cf. Featherstone \& Radaelli, 2003; Olsen, 2002). On one hand, it is described as a top-down process of national adaptation, whereby formal and informal rules, procedures, and norms of the EU policy process cause a reorientation of domestic politics and policy-making (Börzel \& Risse, 2002; Knill \& Lehmkuhl, 2002). Addressees of this mechanism of 'downloading' can be EU member states (causing central penetration of national systems of governance) as well as non-members (causing changes outside the EU's external border). On the other hand, Europeanization is a bottom-up and horizontal process of national projection, whereby domestic preferences, models, and ideas are lifted to the supranational level or transferred to other national levels (Börzel, 2002). At the EU level, this mechanism of 'uploading' typically leads to the development of new institutions, new policies, and capacity building.

Contributions on Europeanization of third countries in the EU's immediate neighbourhood or the wider region generally focus on top-down processes (Börzel, 2011; Gawrich, Melnykovska, \& Schweickert, 2010; Schimmelfennig \& Sedelmeier, 2005; Subotic, 2011). They share an implicit assumption that the EU is the dominant partner in the relationship. As a result, the diffusion of norms and regulations occurs mainly from the EU to the third countries. The same pattern can be seen in the field of energy policy, where the EU is typically perceived as a regulatory and market power (Goldthau \& 
Sitter, 2015, 2019) exporting its model of energy governance. Consequently, the EU energy acquis is expanded beyond Union territory.

This article departs from an EU-centric approach by investigating the possibilities which exist for third countries to shape EU energy policy. Hereby, we focus on European rather than other multilateral policy processes, such as global climate or trade negotiations. The main argument is that the relationship between the EU and third countries in the energy field is more nuanced than generally portrayed: while third countries are not represented in EU decision-making, including on energy, they might still play a role in shaping EU policies. This article investigates third country influence as the ability to shape EU energy policy in line with own preferences (Dür, 2008, p. 561). Influence is exercised at two different stages of the policy cycle: Before (ex-ante) the conclusion of an EU legal act, third countries may seek participation in policy discourses that shape agenda setting and policy formulation (Arts \& Verschuren, 1999, p. 413). After (ex-post) the conclusion of an EU legal act, third countries may be required to implement it. Like EU members, third countries may customize their implementation of the EU energy acquis by tailoring it to domestic needs (Thomann, 2015). However, unlike EU countries, the terms of domestic implementation will usually be subject to negotiations with the EU. Flexible instruments may provide some leeway in this process. The outcome of this process can be considered a form of policy influence because it shapes the overall effects of EU energy policy by defining its geographic boundaries. While recent research has started to describe specific elements of third-country influence (cf. Godzimirski, 2019), this article seeks to offer a more systematic account: What enables third countries to shape EU energy policy ex-ante or ex-post?

We argue that the relative influence of different third countries on EU energy governance depends on two main factors: their access to relevant venues and actors of EU energy policy-making, and their structural power resources. Access to relevant venues and actors of EU energy policy-making may be formal or informal. Formal channels include all frameworks and specific arrangements (e.g., member or observer status) that institutionalize access to six European institutions and bodies with energy governance functions (e.g., via their boards, committees, and working groups): the Commission, the Council, the European Parliament, the Agency for the Cooperation of Energy Regulators (ACER), and the European Network of Transmission System Operators for Electricity (ENTSO-E) and Gas (ENTSO-G). We include ACER and the ENTSOs because the EU's Third Energy Package has provided them with important legal mandates in the completion of the internal energy market, including the development of market and network operation rules, infrastructure plans, and adequacy forecasts. Informal access denotes all contacts with relevant decision-makers outside the six institutions mentioned above, including through participation in loose political forums or ad hoc meetings.
The structural power resources of third countries can turn access into influence. We focus on the role of structural power in adding weight to preferences and arguments of third countries regarding EU policy-making in the areas of electricity and gas. To the extent that third countries implement EU legislation, structural power impacts their ability to customize it, i.e., to negotiate for adjustments and exemptions as well as to make full use of flexible provisions. We thus apply a broader understanding of customization compared with Thomann (2015) since we include the negotiated aspect of ex-post incorporation, which is relevant when analyzing third countries. Third countries can gain structural power because of physical interdependencies with the EU. Scholars have noted that energy import dependencies of the EU can create political leverage for its suppliers, such as Norway and Russia (Godzimirski, 2019, pp. 106-107). This is arguably an important source of power, despite the fact that demand sensitivities can somewhat limit the political leverage of energy producers (Casier, 2011, pp. 497-500).

We posit, however, that the sources of structural power in the energy sector are more diverse (Strange, 1994, pp. 24-42). Besides acting as a major energy supplier, there are three more sources measured by several indicators (Table 1). First, third countries can serve as transit countries for energy supplies and flows. The extent to which third countries can assume powerful transit functions depends on their geographical location, physical grid integration, and competitive position in relation to alternative supply routes (cf. Casier, 2011, p. 496; Haghighi, 2007). Second, third countries can serve as knowledge hubs and technology leaders. Multiple state and non-state actors, including national regulatory authorities, transmission system operators (TSOs), utilities, renewable energy companies, and research institutions, can provide valuable expertise which therefore grants access to EU decision-makers (Bouwen, 2004). Third, non-EU countries with flexible energy sources and highly interconnected grids can serve as flexibility providers. The rapid surge of renewable energies has increased the demand for flexible supply options. Hydropower and gas contribute to supply-side flexibility, and robust, well-designed transmission grids help balance local supply-demand differences (Lund, Lindgren, Mikkola, \& Salpakari, 2015, pp. 797-798). Overall, these sources of structural power play out in many facets of EU electricity and gas policies, including security of supply, infrastructure, internal market, and environment and climate change.

The greater the number of such indicators we can detect within a country-both in terms of quantity and quality-the higher its structural power. While all sources of power matter, we acknowledge that being a large supplier of energy to the EU stands out and may compensate for a lack of other sources. Although conceptually distinct, the relationship between structural power resources and access to relevant venues and actors of 
Table 1. Structural power resources in the energy sector.

\begin{tabular}{ll}
\hline Source of Structural Power & Indicators \\
\hline Energy supplies & - Oil, gas, and electricity supplies \\
\hline Transit Country & - Strategic location in supply corridor \\
& $\bullet$ Interconnectedness of grid \\
& - Limited alternative supply routes \\
\hline Expertise & - Level of technical knowledge \\
& - Experience \\
& - Numbers of energy staff in missions to the EU \\
\hline Flexibility provider & - Installed hydro and gas capacity \\
& - Natural gas production \\
& - Storage capacity \\
& - Number and capacity of grid interconnectors
\end{tabular}

Note: Compiled by the authors.

EU energy policy is complex. Disentangling it would exceed the scope of this article, but we acknowledge that at times the two variables may interact and facilitate one another. Figure 1 illustrates third country influence as we conceptualize it in this article.

Departing from the above conceptualization, we distinguish four ideal-typical roles of third countries in EU energy governance (Table 2). Relative to other third coun- tries, shapers influence EU policy formulation and implementation because of their access and high structural power. Institutionalized relations may require third countries to implement the EU energy acquis but also provide for formal or informal access to EU policy deliberations. Structural power resources allow them to use this access to shape EU policies. The role of shapers thus consists of both (partial) downloading of EU energy poli-

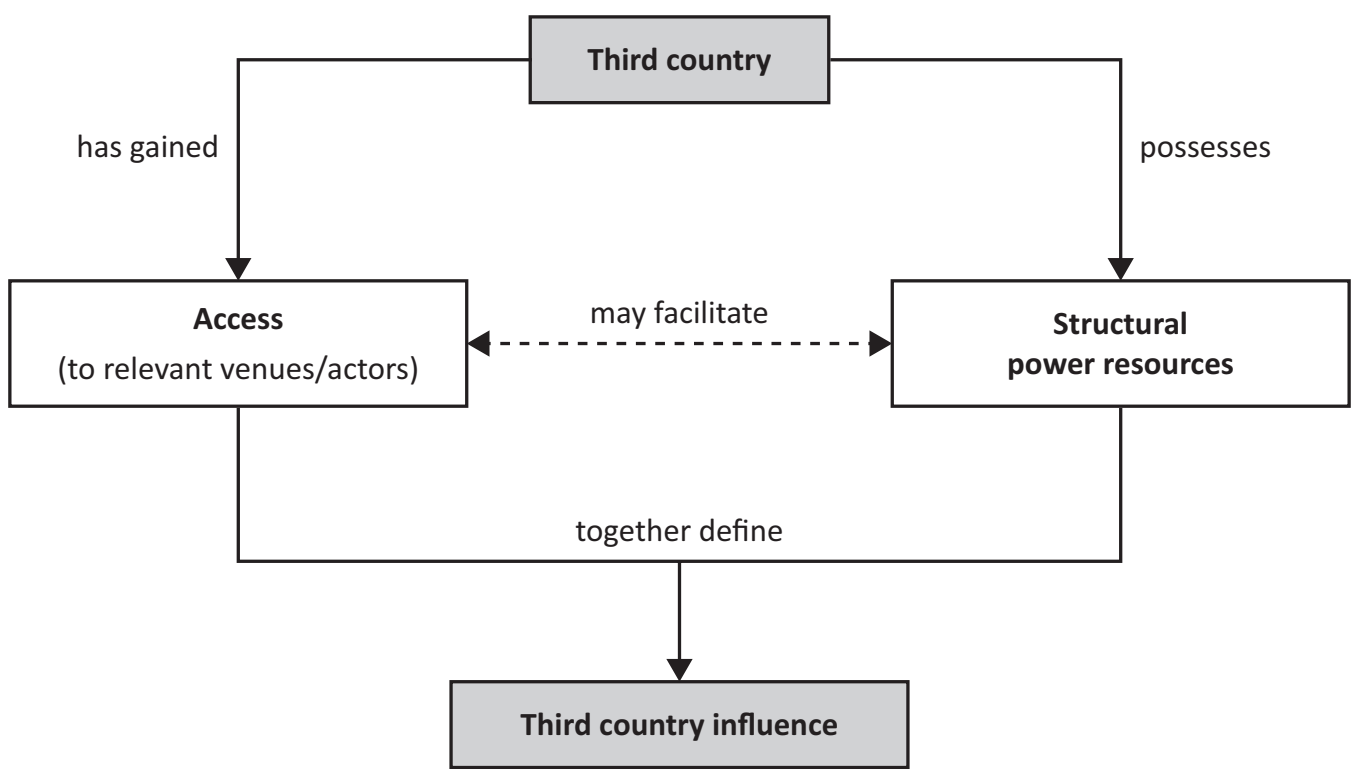

Figure 1. Schematic illustration of third-country influence on EU energy policy. Note: Compiled by the authors.

Table 2. Typology of third countries in EU energy governance.

\begin{tabular}{llllr}
\hline & & \multicolumn{2}{c}{ Third Country Access } \\
\cline { 2 - 4 } Third Country Structural Power Resources & & Absent & Present \\
\hline & High & Challengers & Shapers \\
\cline { 2 - 4 } & Low & Outsiders & Followers \\
\hline
\end{tabular}

Note: Compiled by the authors. 
cies as well as the uploading of own preferences to the European level. Followers also have strong institutional links with the EU but lack significant structural power resources. That is why followers cannot use their access to influence EU policies. Hence, their relationship with the EU primarily consists of downloading rather than uploading. In contrast to shapers and followers, challengers and outsiders have virtually no institutional access to the EU and are not obliged to implement the EU energy acquis. Challengers are third countries possessing high structural power vis-à-vis the EU usually because of their supply or transit functions. As they lack formal access to EU policy processes, their influence will mainly materialize through informal channels and in the context of "high" politics. Outsiders lack the structural power resources of challengers. Accordingly, they have no tangible influence on EU energy policy development.

These ideal type categorizations are admittedly rather coarse. Additional factors may come to shape EUthird country energy relations. They include the similarity of norms of the EU and third countries, mutual economic interests, and the conditionality of EU investments in energy infrastructures abroad (Lavenex, 2004, p. 693; Prange-Gstöhl, 2009, pp. 5300-5302). Nevertheless, our typology is a useful heuristic for understanding the basic configurations of EU-third country relations in energy governance because it facilitates a systematic comparison of third-country influence. Conceptualizing third country influence on EU energy policy as a function of access and structural power resources, we add a novel nuance to the current frameworks. Notably, we allow for variation across countries that exhibit comparable levels of access, yet different structural power resources, and vice versa.

\section{Case Studies of Third Country Influence on EU Energy Policy}

To answer the research question of how third countries can influence EU energy policy, we investigate the role of access in combination with structural power resources. Our analysis includes three cases, each of which represents a different model of cooperation between the EU and third countries: the EnC, Switzerland, and Norway. The EnC is an international organization created by a sectoral multilateral agreement. Today, it is made up of the EU (represented by the European Commission) and nine contracting parties: Albania, Bosnia and Herzegovina, Kosovo, Macedonia, Georgia, Moldova, Montenegro, Serbia, and Ukraine. Switzerland is part of the European Free Trade Area (EFTA) and has defined its political relations with the EU in bilateral agreements. Because these agreements currently do not cover energy, Switzerland autonomously adapts to EU energy legislation and relies on case-by-case arrangements for access to EU governance venues. Norway is also a member of EFTA and, in addition, a part of the EEA (the other members being Iceland and Liechtenstein). As a comprehensive multilateral agreement, the EEA Agreement covers energy amongst other issues. In a structured comparison, we probe our expectation that the EnC countries generally act as followers, whereas Switzerland and Norway are shapers in EU energy policy. The analysis rests on a review of academic and public sources, as well as 15 semi-structured interviews with experts from the EU and national, public, and private organizations.

\subsection{Energy Community: A Follower with New Demands}

Coming into force in 2006, the EnC aims at creating a panEuropean energy market based on EU rules. Contracting parties commit to adopt and apply core parts of the EU energy acquis in their domestic legal systems. Due to legal approximation in the energy field and a close institutional relationship with the EU, the form of integration has been described as an example of sectoral multilateralism (Blockmans \& Vooren, 2012; Petrov, 2012). However, despite an institutional structure designed for the dynamic expansion of the EnC legal framework, the contracting parties have access neither to relevant EU decision-making processes (in the Council and the European Parliament) nor to ACER. Only five of their electricity TSOs are members of ENTSO-E (those from Balkan EnC parties apart from Kosovo) and five gas TSOs have observer status in ENTSO-G (those from Albania, Bosnia and Herzegovina, Macedonia, Moldova, and Ukraine). Moreover, they do not participate in key forums of EU energy policy (such as the Madrid or Florence Forums). Their contact with the Commission is confined to the EnC Ministerial Council where they cannot influence EU policy-making (Interview K, L). Compared to EU member states which can upload their preferences through all of these channels to the European level, EnC contracting parties, therefore, have only a very limited (if not virtually non-existent) voice in future rule-setting (PrangeGstöhl, 2009, p. 5299). This imbalance renders the EU law export to the EnC a legal one-way street.

Regarding structural power resources, EnC countries present a differentiated picture. Their electricity sectors play a minor role in electricity trading because they are relatively small (Balkans and Moldova), partly unsynchronized (Ukraine), or disconnected from other contracting parties (Georgia). With a combined maximum hydro capacity of $8.6 \mathrm{GW}$ (54\% of Swiss hydro capacity), the Balkan EnC members provide some flexibility to the grid of Continental Europe (EnC, 2018; Swiss Federal Office of Energy [SFOE], 2018a). Ukraine is an important transit country for natural gas from Russia. Around $20 \%$ of EU total gas imports pass through its territory, making it a key partner for the security of supply (European Commission, 2018). In this respect, the roles of Albania and Georgia may be enhanced once the Southern Gas Corridor is completed and passes through their territories (Petrov, 2012, p. 337). With few exceptions (Serbia has gained some reputation within ENTSO-E), technical expertise and resources are reportedly less developed across contracting 
parties (Interview K, L). Overall, aside from Ukraine's position in gas transit, individual structural power resources of the contracting parties are therefore negligible.

The individual and collective ex-ante influence of contracting parties on the evolution of the EU energy acquis has been largely insignificant. Individually, they rarely make use of informal channels due to a lack of resources, capacity, and access. Their TSOs experience similar issues in ENTSO-E, resulting, for instance, in a passive role in the Network Code drafting process (Interview K). Collectively, their record for collaboration remains poor despite an institutional framework that is conducive to joint lobbying. Rather to the contrary, initiatives for concerted action occasionally proposed by the EnC Secretariat are often opposed by the contracting parties (Interview $F, L$ ). Reasons include diverse energy market structures resulting in heterogeneous interests. For instance, electricity generation is dominated by hydro (Albania, Montenegro, and Georgia), coal (Kosovo), or gas capacity (Moldova), while Ukraine is the only contracting party with nuclear power (EnC, 2018). Moreover, countries which have a concrete perspective for EU accession (the Western Balkans) tend to avoid conflictive behaviour visà-vis the European Commission (Buschle, 2014; PrangeGstöhl, 2009). Finally, ethnic tensions still politicize technical cooperation on the Balkans. Repercussions are occasionally experienced across Europe, as in the case of a conflict between Serbia and Kosovo which disrupted the electric power grid in early 2018 (cf. Hopkins \& PérezPeña, 2018; Interview F, I). Consequently, EnC members have an underdeveloped culture to coordinate and voice their collective interests, and generally accept the design of energy regulation from Brussels (Interview F, K, L).

Ex-post influence of contracting parties has slowly increased: from the transposition of regulation without changes, via small adaptations reflecting the institutional framework of the EnC, to recent developments potentially enabling substantive customization. Although the EnC Treaty has always provided for customization (Article 24 lays down that the situation of each contracting party must be considered when making changes to the EnC Treaty), this ability has never been used. One reason is that EnC members welcomed the rigid copy-paste transplantation because it promised the establishment of a functioning legal and institutional framework within their territories (Interview F, L). Only lately has Brussels' one-size-fits-all approach to EU rule export across the EnC provoked calls for more flexibility (cf. Buschle, 2014, p. 18). EnC members have developed self-confidence in pronouncing their idiosyncrasies and have started voicing them through alliances with one another. The EU has signalled openness for change. Internally, it has been experiencing a parallel development, turning away from a rigid system of top-down imposition towards pursuing energy and climate goals through nuanced member state contributions. An expansion of this model to nonmembers would necessarily consider national characteristics (Interview L). In 2014, a reform process of the EnC
Treaty was initiated to address the challenges of the agreement. The High-Level Reflection Group, set up to review the effectiveness of the agreement, proposed flexibility in the implementation process to adapt EU rules to the socio-economic situation of contracting parties (EnC, 2014, pp. 11-13). The reform process, which is entering its final phase, could thus entail institutionalized opportunities for legal customization similar to those of the EEA (Interview L).

\subsection{Switzerland: A Shaper at the Crossroads}

Switzerland has access to EU policy deliberations despite not being part of the EEA. Although the bilateral agreements between Switzerland and the EU do not cover energy yet, several institutional arrangements exist in this field. Switzerland is regularly involved in the informal meetings of EU energy ministers as an observer but does not have access to the EU Energy Council and its preparatory bodies (Interview C). Swiss officials may also participate in some expert group meetings of the European Commission (e.g., Gas Coordination Group) as well as in European regulatory forums, including electricity (Florence) and gas (Madrid) (Lavenex, 2015, p. 34). The Swiss national regulatory authority, ElCom, has signed a Memorandum of Understanding with ACER granting it observer status in the organization's Electricity Working Group (Interview A, D). The Swiss electricity TSO, Swissgrid, is a full member of ENTSO-E; the Swiss gas TSOs are associated members or observers of ENTSO-G. The prevalent observer status does not preclude Swiss influence because in most of these forums expertise and deliberation are more important than formal voting (Interview D, I). Switzerland's future access to European institutions depends on the conclusion of an electricity agreement that it has been negotiating with the EU since 2007 (Interview I, J). These negotiations have been severely affected by disagreements on the broader institutional framework between both parties, especially following a Swiss referendum decision in 2014 to limit immigration from the EU (Hettich, Walther, \& Schreiber Tschudin, 2015).

Switzerland has a relatively high level of structural power resources. Its electricity trade relationship with the $\mathrm{EU}$ is one of mutual dependence with net exports to the EU in summer and net imports in winter (SFOE, 2018b). Switzerland is a major transit country for electricity, especially between Central Europe and Italy. It accounts for $10 \%$ of all cross-border electricity flows in continental Europe and one-fifth of the European interconnector capacity (Marcus et al., 2017, p. 43; Pattupara \& Kannan, 2016, p. 153). Switzerland is an electricity hub with long-standing expertise in managing transboundary electricity flows. In the 1950s, its cross-border infrastructure marked the birth of the European electricity grid. Today, Swissgrid is perceived as an active TSO in Central Europe with a high level of technical knowledge (Interview I, J). Additionally, the Swiss mission to the EU is made up of two diplomatic positions in the area of en- 
ergy and climate. Finally, its large hydropower capacities $(16 \mathrm{GW})$ and its highly integrated grid with 41 interconnectors make Switzerland a flexibility provider in the European electricity system (SFOE, 2018a; Interview B).

These relatively high levels of access and structural power resources suggest that Switzerland has some exante influence on EU energy policy. On a technical level, Switzerland has been able to use its formal access to shape the work of ENTSO-E in subsidiary legislation (Interview N). The Swiss TSO has notably taken leading roles in the development of European Network Codes and Guidelines that are prepared by ENTSO-E for adoption by ACER and the European Commission (Interview J, K). Swissgrid's influence is attributed to its proactive attitude, its technical expertise, and the management of key physical and administrative infrastructures in the European grid (Interview D, I, K). On a political level, Swiss influence through formal channels has been more limited. The Swiss national regulatory authority is repeatedly excluded from important meetings of ACER and cannot appeal against decisions which adversely affect Swiss interests. Switzerland is also excluded from activities related to the EU internal market for electricity, such as the Cross-Border Intraday Market Project XBID (Interview A). However, the pressure on Switzerland is somewhat attenuated by the fact that the EU is dependent on Swiss grid infrastructure for integrating Italy into its flow-based market coupling (Interview D, J, M, N). Still, the overall impression is that Switzerland can use formal access more readily for shaping technical rather than political facets of EU energy policy.

Switzerland uploads its preferences to the European level also through informal channels. It is an observer in the Pentalateral Forum - an important venue for discussing electricity matters with all major governance actors from the Central West Europe market region (Interview C, E). Switzerland's participation provides it with early information and opportunities for voicing its concerns to influential EU member states (Interview B, E). Although not an EU body, the Pentalateral Forum has repeatedly shaped EU energy policies through its contacts with the European Commission (Interview B). Moreover, Swiss diplomats have regular bilateral contacts with energy attachés of neighbouring EU countries who are important sources of information and susceptible to Swiss concerns (Interview C). Additionally, shared interests and the provision of technical knowledge have allowed Switzerland to inject policy positions into EU deliberations via Luxembourg (Interview E). The simultaneous use of both formal and informal access points has been particularly effective. For instance, Swiss actors were able to shape parts of the Electricity Balancing Guideline to suit them better by articulating a joint position through various channels (Interview C). Hence, Switzerland voices and to some extent even successfully uploads its policy preferences to the European level.

Ex-post influence is currently not relevant for Switzerland because it is not legally bound to implement the EU energy acquis but autonomously adapts to new EU legislation (Marcus et al., 2017, p. 39). Consequently, the energy laws of Switzerland and the EU take similar strategic directions but differ in various specific aspects (Interview $A, D, H)$. In the future, pressures for stronger Swiss convergence with the EU energy acquis will rise to the extent that Switzerland wishes to participate in the EU internal market for electricity (ACER, 2018, p. 2; Interview D, J). In sum, Switzerland finds itself at a crossroads: The (non-)conclusion of an institutional and an electricity agreement with the EU will affect its European market integration as well as its ability to shape EU energy policy (cf. also van Baal and Finger, 2019, in this issue).

\subsection{Norway: A Reactive Shaper}

Norway has been part of the EU's Single Market through the EEA Agreement since 1994. The prerequisite is the implementation of 'EEA-relevant' EU legislation, although a veto option exists. Beyond market legislation, relevance is assessed based on what was previously incorporated, and subject to negotiations between the EU and the EEA countries (Buschle \& Jourdan-Andersen, 2016). Norway does not have political representationor voting rights-inside the EU institutions and has no access to the political negotiations on proposed legislation in the Council or in the European Parliament (Interview $\mathrm{G}, \mathrm{O})$. Among EEA members, only Norway as a major energy provider holds an annual bilateral energy dialogue with the Commission, which it has since 2002 (Ministry of Petroleum and Energy, 2017, p. 4). However, the EEA countries may collectively comment on Commission initiatives, and the EEA agreement grants them access to Commission (comitology) committees. Experts from EEA countries may also participate as observers in Commission expert committees and working groups, as well as in EU agencies. The latter requires implementation of the relevant legislation, so the Norwegian energy agency's access to observe ACER board meetings remains on hold due to delays implementing the Third Energy Package (see below). The Norwegian gas TSO (Gassco) is an observer in ENTSO-G, while the Norwegian electricity TSO (Statnett) is a full member of ENTSO-E with voting rights and a high-ranking representative on its board.

In regard to structural power resources, Norway is the second-largest provider of oil and gas to the EU, contributing $12 \%$ of oil and $23 \%$ of gas imports (Eurostat, 2018). With minimal domestic gas consumption, Norway has built pipelines exclusively for export to Europe. Its electricity system is based predominantly on hydro which provides flexibility to an interconnected Nordic market. Interconnectors also exist with the Netherlands and are under construction with Germany and the UK. Overall, Norway is a net exporter of electricity to the EU. Finally, Norway has permanent representation in Brussels, with two diplomatic staff working on energy (Norwegian Mission, 2018). With early domestic liberalization and regional integration of electricity, Norwegian public 
and private actors have extensive experience to build on (Jevnaker, 2014; Interview G, I, O).

Norway uses its access to the Commission to seek exante influence. Experts from EEA energy ministries and DG Energy meet to discuss upcoming and adopted EU legislation, and the Commission is characterized as receptive to discussing new initiatives (Interview G). While EEA countries rarely (and never since 2008) submit formal joint comments to the Commission on upcoming energy legislation (EFTA, 2018), Norway has submitted nonpapers individually as well as jointly with EU member states (Interview G, see also Szulecki, Fischer, Gullberg, \& Sartor, 2016). Moreover, Norway uses the energy dialogue for political talks with the Commission (Jevnaker, 2014, p. 18), most recently in 2016 (Interview G). Norway does not have privileged access to the European Parliament (Interview G, O), but has been invited to informal Council sessions since 2003. Nordic-Baltic meetings ahead of the formal Council sessions allow Norway to present its interests to EU member states. Norway also ensures that it has a meeting with the incoming Council presidency to inform that member state about the EEA Agreement (Interview G). Generally, Norwegian politicians have weak incentives to prioritize informal channels vis-à-vis the Council due to their inability to participate in formal sessions or negotiations (Trondal \& Stie, 2015; Interview G). Norwegian experts participate in comitology committees on energy-related issues (Jevnaker, 2014, 2016). Although major Norwegian energy companies and associations are actively engaged in Brussels (Interview O)-including via EU associationsthey mainly lobby in Norway to influence EU decisionmaking processes (Gullberg, 2015). However, Statnett is a central player due to its expertise and use of resources, dedicating a large number of staff to, and having experience with, liberalization and regional energy market integration (Interview I). Participation without representation in the EU generally leaves Norway's management of its EU relations to the administration (Trondal \& Stie, 2015), with weak political impetus behind Norwegian use of available channels for ex-ante influence.

Regarding ex-post influence, EEA incorporation of the energy acquis is subject to negotiation, where adjustments represent a form of customization. Moreover, not all EU energy legislation is relevant to the EEA. For instance, the Common European Facility, which also funds energy infrastructure, was defined as a budget issue which is outside the scope of the EEA Agreement. In practice, whether an act is classified as EEA relevant or not involves some political discretion that can be exploited through good reasoning (Interview G). Nevertheless, Norwegian arguments carried additional weight due to Norway's strategic energy assets. Norway has resisted most EU legislation on offshore issues to protect its petroleum sector, disputing relevance on grounds that its continental shelf-where petroleum extraction takes place-is outside the EEA's geographical jurisdiction (Norwegian Ministry of Foreign Affairs, 2012, p. 13).
Outright rejection of EEA-relevant legislation has occasionally been discussed in Norway (for energy: the 1994 licensing directive, the 1998 gas market directive, and the 2009 ACER Regulation), but a formal veto has never been effectuated (NOU, 2012, p. 103). Instead, the EU and the EEA countries have negotiated on adjustments and derogations for specific articles in difficult EU energy legislation prior to EEA incorporation, for instance, deciding on a lower renewables target for Norway than was anticipated from the EU's methodology (Jevnaker, 2016). Negotiations on adjustments are sometimes linked to discussions on EEA relevance and a potential veto, whereby resistance and disagreements can prolong the process. EEA incorporation needs unanimous support from the EEA countries (Buschle \& Jourdan-Andersen, 2016), so delays in one country prevent application everywhere. At the time of writing, the Third Energy Package of 2009 was still awaiting Icelandic parliamentary approval. Finally, EEA countries can customize implementation where there is flexibility in EU legislation. On energy, Norway used this option to uphold domestic practices, for example, reinforcing public ownership when EU legislation banned the differential treatment of public and private ownership in licensing contracts on energy (Austvik \& Claes, 2011).

\section{Comparing Followers and Shapers}

This section discusses the findings of the empirical case studies in light of our conceptual framework. The cases exhibit very different degrees of ex-ante influence. Lacking access to relevant venues and actors, the EnC plays no active role in EU policy-making. Where there is only weak potential for formal or informal access, low structural power often impedes the exploitation of these channels. Switzerland makes more and effective use of its formal access to certain European bodies, in particular to ENTSO-E where it successfully draws on its expertise to influence the technical aspects of EU regulation. It also actively utilizes informal channels to upload its preferences on political aspects of EU energy legislation. Among our cases, Norway has the most access and possesses sufficient structural power resources to exploit it. As for Switzerland, expertise and capacity generate leverage in European bodies such as ENTSO-E. Nevertheless, Norway's influence is somewhat compromised by the lack of attention given to the matter by its politicians, which has largely left Norwegian engagement visà-vis the EU to bureaucrats and stakeholders.

In all case studies, a clear distinction was found between influence over political as compared to more administrative and technical policy-making. The political venues in the EU (the European Parliament and the Council) are mainly off limits to the third countries studied here. By contrast, the more technical and administrative venues for the development of EU subsidiary legislation (European Commission working groups, ACER, and the ENTSOs) are more amenable to third countries. Strik- 
ingly, the ex-ante influence of third countries here may even surpass that of certain EU member states. In this context, an EU official involved in high-level EU energy policy-making stated that "the de-facto power and representation of Switzerland without voting rights is many times higher than a small Eastern European member state with voting rights" (Interview J, own translation). Our analysis suggests that this assessment may be extended to Norway. Nevertheless, while the case studies indicate instances of influence during policy-making, an investigation of the relative impact on adopted legal acts exceeds the scope of this analysis.

An assessment of ex-post influence on EU energy policy through customization revealed diversity across the cases. Empirical evidence suggests a link between access and structural power on one hand and ex-post influence on the other hand. Essentially copy-pasting the EU energy acquis, the EnC has long been a prime example of top-down Europeanization of third countries. Only lately did the contracting parties signal interest to move towards a more balanced relationship. A model could be the EEA, which despite an obligation to adopt relevant EU energy legislation grants its members some scope for negotiated adjustments. This requires reasoned argumentation, which may carry more weight if the country possesses structural power-such as Norway. Still, even Norway is not always granted adjustments. In contrast, Switzerland does not need ex-post influence because it is not legally required to transpose EU energy legislation and autonomously adapts to it instead. In practice, Swiss energy policy takes similar strategic directions to EU legislation but deviates in its substantive provisions.

Among the three cases, Switzerland enjoys the largest leeway for formulating an energy policy that considers domestic needs. This is not surprising given the bilateral framework for cooperation with the EU which does not entail automatic law export in either direction. Nevertheless, the bilateral path to energy sector integration has become increasingly cumbersome for the EU (cf. Buschle, 2014). The difficulties experienced when trying to conclude an electricity agreement with Switzerland suggest that multilateral agreements may better suit EU interests. From a Brussels perspective, the multilateral model promises economies of scale, since it fa- cilitates the export of EU law to more than one country. A functioning framework can also attract other third countries to join the agreement. Moreover, the two multilateral frameworks currently in place have shown that integration does not have to come at the price of rigidity: customization as already practised in the EEA-and as discussed in the reform process of the EnC-can provide for at least some flexibility. This corresponds to the idea of a modern, goal-oriented form of governance that accommodates diversity and integrates heterogeneous countries into a single legal space.

This diversity is reflected in the different roles that individual countries may play in relation to EU energy policy-making (see Table 3). Among our cases, both Norway and Switzerland are shapers of EU energy policy. They can upload their preferences to the European level thanks to their access to relevant policy venues and actors and their relatively high structural power resources. These countries have a particular status in relation to the EU, making them more than 'pure' third countries. While Norway ranks higher on both variables, it is mainly a reactive shaper as it uses most of its influence in the ex-post stage. Switzerland is a shaper of EU energy policy formulation but presently finds itself at a crossroads. Failure to achieve an electricity agreement with the EU will likely come at the expense of market and political access (Interview J). Switzerland is thus at risk of losing its shaper role. The $\mathrm{EnC}$ is a follower and despite the differences in structural power resources among its members (six countries from the Western Balkans, Georgia, Moldova and Ukraine), all of them fall short of being shapers. The EnC reform process is unlikely to change this.

Future research could locate other third countries within this framework. Tentatively (marked in Table 3 in brackets), we assume that Russia's high structural power (oil and gas supplier) and comparatively low access (Energy Dialogue) make it an almost ideal typical challenger. As an important transit country within the EU's strategy to diversify supply routes (Southern Gas Corridor), Turkey also falls within this category. The low structural power of Belarus (transit country bypassed by Ukraine and Nord Stream) and its lack of access render it an outsider. Iceland, with a fair degree of access (EEA) yet low structural power (energy island), is a follower.

Table 3. Third country roles in EU energy policy.

\begin{tabular}{|c|c|c|c|}
\hline & & \multicolumn{2}{|c|}{ Third Country Access } \\
\hline & & Absent & Present \\
\hline \multirow{2}{*}{ Third Country Structural Power Resources } & High & $\begin{array}{c}\text { Challengers } \\
\text { (Russia) } \\
\text { (Turkey) }\end{array}$ & $\begin{array}{c}\text { Shapers } \\
\text { Norway } \\
\text { Switzerland }\end{array}$ \\
\hline & Low & $\begin{array}{l}\text { Outsiders } \\
\text { (Belarus) }\end{array}$ & $\begin{array}{c}\text { Followers } \\
\text { EnC members } \\
\text { (Iceland) }\end{array}$ \\
\hline
\end{tabular}

Note: Compiled by the authors. 


\section{Conclusion}

In this article, we explored the relative influence of third countries on EU energy policy. In contrast to one-sided concepts of Europeanization, we argued that non-EU member states can indeed exert influence on EU energy governance. The relative influence of third countries is a function of their access to relevant EU policy venues and actors, and their structural power resources. We empirically probed our argument in three case studies which represented different institutional models of EU-third country cooperation. We found the nine Southeast and East European states that are parties to the EnC to be followers of EU energy policy. Recently, however, they have voiced demands for greater flexibility in the transposition of the energy acquis. By contrast, Switzerland (bilateral arrangements) and Norway (EEA member) act as shapers of EU energy policy-although with some limitations: Switzerland currently faces uncertainties regarding its future access to European institutions; Norway has generally taken a more reactive stance. Nonetheless, we find it striking that these two non-members are held to sometimes have even more influence on EU energy policy than some EU member states with voting rights. Future research could examine this further by means of indepth case studies of third-country influence in specific policy processes.

What does our research reveal about the future of the UK in EU energy governance? Its role will partly depend on access to European institutions. The EU seeks to avoid giving institutional and market access to third countries without requiring them to follow EU rules, as its harsher stance towards Switzerland illustrates. Models for future EU-UK cooperation could hence be the electricity agreement between the EU and Switzerland or the more extensive EEA Agreement. Notwithstanding this choice, the UK is losing important structural power due to decreasing fossil fuel production and supplies to the EU. Its electricity interconnection with Ireland and Continental Europe may matter for the internal market, but its island position naturally limits transit functions. The UK could gain some leverage though through its expertise in energy markets and liberalization. Irrespective of what access the UK should get to the EU via a Brexit agreement, our framework thus predicts difficulties in exploiting channels of influence. The UK, therefore, finds itself at a crossroads of its future energy relations with the Union. If upcoming political decisions led to the loss of British access to most EU policy venues, the UK could become an outsider according to our framework.

Brexit is the most obvious reason why systematic research on the role of third countries in EU policy-making is timely. Our contribution to this emerging research agenda is to highlight that the Europeanization of energy policy works in two directions-also with third countries. The EU regulatory regime is not immune to external influence. Depending on their access and structural power, third countries can follow, challenge, and even shape EU energy policy.

\section{Acknowledgments}

The authors thank David Kolcava for valuable research assistance. This research project is part of the activities of SCCER CREST (Swiss Competence Center for Energy Research), which is financially supported by Innosuisse under Grant No. KTI. 1155000154, and of the National Research Programme "Energy Turnaround" (NRP 70) of the Swiss National Science Foundation (SNSF). Support was also provided by the Centre for International Climate and Energy Policy (CICEP).

\section{Conflict of Interests}

The authors declare no conflict of interests.

\section{References}

Agency for the Cooperation of Energy Regulators. (2018). Opinion No 02/2018 of 10 April 2018 on the participation of Switzerland in the European platforms for the exchange of standard products for balancing energy in accordance with article 1(7) of commission regulation (EU) 2017/2195 of 23 November 2017 establishing a guideline on electricity balancing. Ljubljana: Agency for the Cooperation of Energy Regulators.

Arts, B., \& Verschuren, P. (1999). Assessing political influence in complex decision-making: An instrument based on triangulation. International Political Science Review, 20(4), 411-424.

Austvik, O. G., \& Claes, D. H. (2011). EØS-avtalen og norsk energipolitikk [The EEA Agreement and Norwegian energy policy] (No. 8). Oslo: Europautredningen.

Blockmans, S., \& Vooren, B. V. (2012). Revitalizing the European "neighbourhood economic community": The case of legally binding sectoral multilateralism. European Foreign Affairs Review, 17(4), 577-604.

Börzel, T. (2002). Member state responses to Europeanization. JCMS: Journal of Common Market Studies, 40(2), 193-214.

Börzel, T. (2011). When Europe hits...beyond its borders: Europeanization and the near abroad. Comparative European Politics, 9(4/5), 394-413.

Börzel, T., \& Risse, T. (2002). When Europe hits home: Europeanization and domestic change (SSRN Scholarly Paper No. 302768). Rochester, NY: Social Science Research Network. Retrieved from https://papers.ssrn. com/abstract $=302768$

Bouwen, P. (2004). Exchanging access goods for access: A comparative study of business lobbying in the European Union institutions. European Journal of Political Research, 43(3), 337-369.

Buchan, D. (2015). Energy policy: Sharp challenges and rising ambitions. In H. Wallace, M. A. Pollack, \& A. R. Young (Eds.), Policy-making in the European Union 
(7th ed., pp. 344-366). Oxford: Oxford University Press.

Buschle, D. (2014). Exporting the internal marketPanacea or nemesis for the European neighbourhood policy? Lessons from the Energy Community (EU Diplomacy Paper No. 2/2014). Bruges: College of Europe.

Buschle, D., \& Jourdan-Andersen, B. (2016). Energy law. In C. Baudenbacher (Ed.), The handbook of EEA law (pp. 773-805). Cham: Springer International Publishing.

Casier, T. (2011). Russia's energy leverage over the EU: Myth or reality? Perspectives on European Politics and Society, 12(4), 493-508.

Cowles, M. G., Caporaso, J., \& Risse, T. (Eds.). (2001). Transforming Europe: Europeanization and domestic change. Ithaca, NY: Cornell University Press.

Dür, A. (2008). Measuring interest group influence in the EU: A note on methodology. European Union Politics, 9(4), 559-576.

European Free Trade Association. (2018). EEA EFTA comments. European Free Trade Association. Retrieved from http://www.efta.int/eea/eea-efta-comments

Energy Community. (2014). An Energy Community for the future (Report by the High-Level Reflection Group of the Energy Community). Vienna: Energy Community Secretariat.

Energy Community. (2018). Energy sector benchmark data: Facts and figures 2017. Energy Community. Retrieved from https://www.energy-community.org/ implementation

European Commission. (2018). Quarterly report on European gas markets (Market Observatory for Energy). Brussels: DG Energy.

Eurostat. (2018). Energy production and imports. Eurostat. Retrieved from https://ec.europa.eu/eurostat/ statistics-explained/index.php/Energy_production and_imports

Featherstone, K., \& Radaelli, C. M. (2003). The politics of Europeanization. Oxford: Oxford University Press.

Gawrich, A., Melnykovska, I., \& Schweickert, R. (2010). Neighbourhood Europeanization through ENP: The case of Ukraine. JCMS: Journal of Common Market Studies, 48(5), 1209-1235.

Godzimirski, J. M. (2019). Channels of influence or how non-members can influence EU energy policy. In J. M. Godzimirski (Ed.), New political economy of energy in Europe: Power to project, power to adapt (pp. 105-137). London: Palgrave Macmillan.

Goetz, K. H., \& Hix, S. (2000). European integration and national political systems. West European Politics, 23(4), 1-26.

Goldthau, A., \& Sitter, N. (2015). A liberal actor in a realist world: The European Union regulatory state and the global political economy of energy. Oxford: Oxford University Press.

Goldthau, A., \& Sitter, N. (2019). Regulatory or market power Europe? EU leadership models for interna- tional energy governance. In J. M. Godzimirski (Ed.), New political economy of energy in Europe: Power to project, power to adapt (pp. 27-47). London: Palgrave Macmillan.

Gullberg, A. T. (2015). Lobbying in Oslo or in Brussels? The case of a European Economic Area country. Journal of European Public Policy, 22(10), 1531-1550.

Haghighi, S. S. (2007). Energy security: The external legal relations of the European Union with major oil and gas supplying countries. Oxford: Hart Publishing.

Hettich, P., Walther, S., \& Schreiber Tschudin, S. (2015). Schweiz ohne Stromabkommen [Switzerland without energy agreement]. Zurich and St.Gallen: Dike.

Hopkins, V., \& Pérez-Peña, R. (2018, March 9). Clocks slow in Europe? Blame Kosovo-Serbia row. The New York Times. Retrieved from https://www.nytimes. com/2018/03/08/world/europe/kosovo-serbia-clocks -europe.html

Jegen, M. (2009). Swiss energy policy and the challenge of European governance. Swiss Political Science Review, 15(4), 577-602.

Jevnaker, T. (2014). Norway's implementation of the EU climate and energy package: Europeanization or cherry-picking? (FNI Report No. 7/2014). Lysaker: Fridtjof Nansen Institute.

Jevnaker, T. (2016). Norway. In J. B. Skjærseth, P. O. Eikeland, L. H. Gulbrandsen, \& T. Jevnaker (Eds.), Linking EU climate and energy policies: Decision-making, implementation and reform. Cheltenham: Edward Elgar Publishing.

Knill, C., \& Lehmkuhl, D. (2002). The national impact of European Union regulatory policy: Three Europeanization mechanisms. European Journal of Political Research, 41(2), 255-280.

Lavenex, S. (2004). EU external governance in 'wider Europe'. Journal of European Public Policy, 11(4), 680-700.

Lavenex, S. (2015). Experimentalist governance in EU neighbourhood policies: Functionalist versus political logics. In J. Zeitlin (Ed.), Extending experimentalist governance? The European Union and transnational regulation (pp. 23-49). Oxford: Oxford University Press.

Lund, P. D., Lindgren, J., Mikkola, J., \& Salpakari, J. (2015). Review of energy system flexibility measures to enable high levels of variable renewable electricity. Renewable and Sustainable Energy Reviews, 45, 785-807.

Marcus, J. S., Petropoulos, G., Sapir, A., Tagliapietra, S., Terzi, A., Veugelers, R., \& Zachmann, G. (2017). Review of EU-third country cooperation on policies falling within the ITRE domain in relation to Brexit (No. IP/A/ITRE/2017-001). Brussels: European Parliament, ITRE.

Ministry of Petroleum and Energy. (2017). EU-strategi for Olje- og energidepartementet [EU strategy for the Ministry of Petroleum and Energy]. Oslo: Ministry of Petroleum and Energy. Retrieved from https://www. 
regjeringen.no/contentassets/8a78084bae474de488 833fe129d11228/oeds-eu-strategi_2018_endelig.pdf Norwegian Ministry of Foreign Affairs. (2012). The EEA agreement and Norway's other agreements with the EU (Report to the Storting No. Meld. St. 5 (2012-2013). Oslo: Norwegian Ministry of Foreign Affairs. Retrieved from https://www.regjeringen.no/ globalassets/upload/ud/vedlegg/europa/nou/meldst5 _ud_eng.pdf

Norwegian Mission. (2018). Staff list: Norway-Mission to the EU. Retrieved from https://www.norway.no/ en/missions/eu/about-the-mission/about

NOU. (2012). Innenfor og utenfor: Norges avtaler med EU [Inside and outside: Norway's agreements with the EU] (NOU 2012 (2)). Oslo: Norges offentlige utredninger.

Olsen, J. P. (2002). The many faces of Europeanization. JCMS: Journal of Common Market Studies, 40(5), 921-952.

Pattupara, R., \& Kannan, R. (2016). Alternative lowcarbon electricity pathways in Switzerland and it's neighbouring countries under a nuclear phase-out scenario. Applied Energy, 172, 152-168.

Petrov, R. (2012). Energy community as a promoter of the European Union's 'Energy Acquis' to its neighbourhood. Legal Issues of Economic Integration, 39(3), 331-355.

Prange-Gstöhl, H. (2009). Enlarging the EU's internal energy market: Why would third countries accept EU rule export? Energy Policy, 37(12), 5296-5303.

Schimmelfennig, F., \& Sedelmeier, U. (Eds.). (2005). The Europeanization of Central and Eastern Europe.
Ithaca, NY: Cornell University Press.

Swiss Federal Office of Energy. (2018a). Statistik der Wasserkraftanlagen der Schweiz [Statistics of Swiss hydropower plants]. Bern: Swiss Federal Office of Energy.

Swiss Federal Office of Energy. (2018b). Physikalische Einfuhr und Ausfuhr der Schweiz nach Ländern [Physical imports and exports of Switzerland by country]. Bern: Swiss Federal Office of Energy.

Strange, S. (1994). States and markets (2nd ed.). London and New York: Continuum.

Subotic, J. (2011). Europe is a state of mind: Identity and Europeanization in the Balkans. International Studies Quarterly, 55(2), 309-330.

Szulecki, K., Fischer, S., Gullberg, A. T., \& Sartor O. (2016). Shaping the 'Energy Union': Between national positions and governance innovation in EU energy and climate policy. Climate Policy, 16(5), 548-567.

Thaler, P. (2016). The European Commission and the European Council: Coordinated agenda setting in European energy policy. Journal of European Integration, 38(5), 571-585.

Thomann, E. (2015). Customizing Europe: Transposition as bottom-up implementation. Journal of European Public Policy, 22(10), 1368-1387.

Trondal, J., \& Stie, A. E. (2015). Blir handlingsrommet større med egen europaminister? [A Norwegian minister of European Affairs: what difference does it make?] Nytt Norsk Tidsskrift, 32(2), 123-134.

Van Baal, P. A., \& Finger, M. (2019). The effect of European integration on Swiss energy policy and governance. Politics and Governance, 7(1), 6-16.

\section{About the Authors}

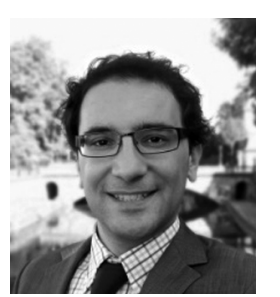

Benjamin Hofmann is a Research Associate and PhD Candidate in International Affairs at the Institute of Political Science, University of St. Gallen, Switzerland. He holds an MA in Political Science from the University of Salzburg and has served as Policy Officer at an international governmental organization in the field of sustainable transport. His main research areas are Swiss energy governance and the role of business actors and technology in the international environmental regulation of maritime industries.

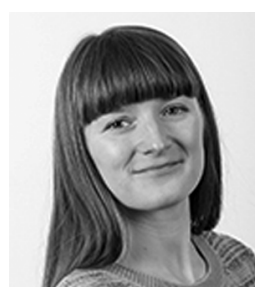

Torbjørg Jevnaker is a Research Fellow at the Fridtjof Nansen Institute, Norway, and a PhD Candidate at the Department of Political Science, University of Oslo, Norway. Her research focuses on public policy and regulation, especially with regard to EU climate and energy governance. She has published works on energy market regulation and emissions trading, as well as Norwegian implementation of EU legislation. Photo credit: Tron Trondal (2016).

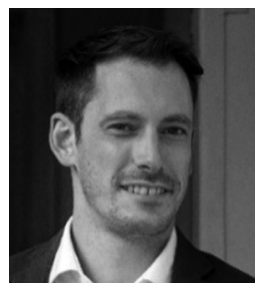

Philipp Thaler is a Postdoctoral Researcher for Energy Governance at the Institute of Political Science, University of St. Gallen, Switzerland. He holds a PhD in Political Science from Central European University, an MA from the London School of Economics, and a BA from Maastricht University. His research interests include energy and climate governance and EU external relations. Besides academia, he has more than five years of private, public, and non-profit sector experience in the field of energy. 


\section{Cogitatio}

\section{Appendix}

\section{List of Interviews}

\begin{tabular}{ll}
\hline Interview & Affiliation of interview partner \\
\hline A & Nation state official \\
B & Nation state official \\
C & Nation state official \\
D & Nation state official \\
E & Nation state official \\
F & Nation state official \\
G & Nation state official \\
H & Subnational official \\
I & European institution \\
J & European institution \\
K & International organization \\
L & International organization \\
M & Private sector \\
$\mathrm{N}$ & Private sector \\
$\mathrm{O}$ & Private sector \\
\hline
\end{tabular}

